\title{
The Application of Fiber Ion Exchange Sorbents for Wastewater Treatment and Purification of Gas Mixtures
}

\author{
Ilnur Garipov ${ }^{1}$, Renat Khaydarov ${ }^{1,}$, , Olga Gapurova ${ }^{1}$, Rashid Khaydarov ${ }^{1}$, \\ Svetlana Evgrafova ${ }^{2,3}$ \\ ${ }^{1}$ Laboratory of Interdisciplinary Technologies, Institute of Nuclear Physics, Uzbekistan Academy of Sciences, Tashkent, Uzbekistan \\ ${ }^{2}$ Department of Biotechnology, Siberian Federal University, Krasnoyarsk, Russia \\ ${ }^{3}$ Laboratory of Ecophysiology of Permafrost Systems, V. N. Sukachev Institute of Forest FRC KSC SB RAS, Krasnoyarsk, Russia
}

Email address:

renat2@gmail.com (R. Khaydarov)

${ }^{*}$ Corresponding author

\section{To cite this article:}

Ilnur Garipov, Renat Khaydarov, Olga Gapurova, Rashid Khaydarov, Svetlana Evgrafova. The Application of Fiber Ion Exchange Sorbents for Wastewater Treatment and Purification of Gas Mixtures. Journal of Energy, Environmental \& Chemical Engineering.

Vol. 5, No. 1, 2020, pp. 10-13. doi: 10.11648/j.jeece.20200501.12

Received: May 7, 2020; Accepted: May 26, 2020; Published: June 15, 2020

\begin{abstract}
We developed a method of modifying the polyester material to produce ion exchange fiber sorbents. The production of cation exchange sorbents involved the treatment of polyester fibers with a $20-25 \%$ solution of $\mathrm{NH}_{2} \mathrm{NH}_{2} \mathrm{H}_{2} \mathrm{O}$ at $70-90^{\circ} \mathrm{C}$ and a $5 \%$ solution of $\mathrm{NaOH}$ at $40^{\circ} \mathrm{C}$. Anion exchange sorbents were prepared by the treatment of cation exchange sorbents with a 1$5 \%$ solution of polyethylenimine at ambient temperature. These new types of sorbents can be used to remove radionuclides, heavy metal ions and organic contaminants from wastewater and drinking water. We studied main properties of these sorbents and their ability to remove ${ }^{57} \mathrm{Co},{ }^{60} \mathrm{Co},{ }^{65} \mathrm{Zn},{ }^{89} \mathrm{Sr},{ }^{90} \mathrm{Sr},{ }^{134} \mathrm{Cs},{ }^{137} \mathrm{Cs}$ and other radionuclides, heavy metal ions ( $\mathrm{Zn}, \mathrm{Ni}, \mathrm{Cu}, \mathrm{Sb}, \mathrm{Pb}$, $\mathrm{Cd}, \mathrm{Cr}$, $\mathrm{U}$, etc.), organic molecules $\mathrm{M}$ (pesticides, phenols, dioxins, benzene, toluene, etc.), radio-labeled organic molecules $\mathrm{M}-{ }^{32} \mathrm{P}, \mathrm{M}-{ }^{131} \mathrm{I}, \mathrm{M}-{ }^{99} \mathrm{Mo}^{+99 \mathrm{~m}} \mathrm{Tc}, \mathrm{M}-{ }^{14} \mathrm{C}$, etc. The static exchange capacity is $1-2 \mathrm{meq} / \mathrm{g}$ for cationic sorbents and $0.5-1 \mathrm{meq} / \mathrm{g}$ for anionic sorbents. The developed sorbents have been effective in removing low concentrations of contaminants from water (lower than $100-200 \mathrm{mg} / \mathrm{L}$ ) as well as in purifying the gas mixtures from toxic and aggressive gases: $\mathrm{SO}_{2}, \mathrm{SO}_{3}, \mathrm{NH}_{3}, \mathrm{H}_{2} \mathrm{~S}$, etc.
\end{abstract}

Keywords: Polyester, Cation Exchange, Anion Exchange, Fiber Sorbent, Wastewater Treatment

\section{Introduction}

Drinking water and wastewater purification from radionuclides, heavy metal ions and organic contaminants is one of the most important problems of the modern world. To solve it, the ion exchange method utilizing different types of resins and fiber sorbents [1] is widely used.

The advantage of fiber ion-exchange sorbents over resin is their high sorption rate, effective regeneration and a low pressure drop value of the sorbent layer for purified water [2-4]. The specific surface of fiber sorbents is $(2-3) \cdot 10^{4} \mathrm{~m}^{2} / \mathrm{kg}$, i.e. about $10^{2}$ times greater than that of resin $\left(10^{2} \mathrm{~m}^{2} / \mathrm{kg}\right)$. Due to that, fiber sorbents have a much higher sorption rate than resin.

The main drawback of fiber sorbents is their very low specific weight which is $50-200 \mathrm{~kg} / \mathrm{m}^{3}[5-8]$.
There are many fiber filters produced in various plants, but most of them are intended only for air purification from dust and aerosols, and they do not have ion-exchange properties. The purpose of this work is to develop a technology for producing dust fiber filters with ion exchange properties. In many cases, this approach is economically more effective because it does not require construction of new plants. One of the most produced dust filters is a polyester fiber filter. Its production process includes acrylonitrilic emulsion treatment to improve mechanical characteristics. This feature can be used in the technology for producing cation and anion exchange sorbents.

\section{Materials and Methods}

A polyester fiber filter with surface density of $0.270 \mathrm{~kg} / \mathrm{m}^{2}$ 
and thickness of $10 \mathrm{~mm}$ was utilized as a raw material for making ion exchange sorbents. The mass of the polyacrylonitrilic layer on the fibers' surface was $15 \%$ of the total mass of the filter.

$1-10 \% \mathrm{NaOH}$ solutions and $0.5-5 \%$ polyethylenimine $\left(-\mathrm{NHCH}_{2} \mathrm{CH}_{2}-\right)_{\mathrm{x}}\left[-\left(\mathrm{CH}_{2} \mathrm{CH}_{2} \mathrm{NH}_{2}\right) \mathrm{CH}_{2} \mathrm{CH}_{2}-\right]_{y}$ solutions were used for the treatment of polyester fiber filters to make ion exchange sorbents.

The $0.001 \mathrm{M} \mathrm{CuCl}_{2}$ solution labeled by ${ }^{64} \mathrm{Cu}$ and the $\mathrm{K}_{2} \mathrm{Cr}_{2} \mathrm{O}_{7}$ solution ( $\mathrm{pH}$ 2) labeled by ${ }^{51} \mathrm{Cr}$ were used to find out the best technology of making cation and anion exchange sorbents, respectively. The radionuclides ${ }^{64} \mathrm{Cu}$ and ${ }^{51} \mathrm{Cr}$ were produced by irradiating $\mathrm{CuCl}_{2}$ and $\mathrm{K}_{2} \mathrm{Cr}_{2} \mathrm{O}_{7}$ in the nuclear reactor of the Institute of Nuclear Physics (Tashkent, Uzbekistan). A Ge(Li) detector with a resolution of about 1.9 $\mathrm{keV}$ at $1.33 \mathrm{MeV}$ and a 4096-channel multichannel analyzer were used to detect a $\gamma$-quantum from radionuclides. Areas under $\gamma$-peaks of radionuclides ${ }^{64} \mathrm{Cu}$ (the half-life, $\mathrm{T}_{1 / 2}$, is equal to $12.8 \mathrm{~h}$, the energy of the $\gamma$-peak, $\mathrm{E}_{\gamma}$, is equal to 0.511 $\mathrm{MeV}$ ) and ${ }^{51} \mathrm{Cr}$ (the half-life, $\mathrm{T}_{1 / 2}$, is equal to $27.72 \mathrm{~d}$, the energy of the $\gamma$-peak, $E_{\gamma}$, is equal to $0.320 \mathrm{MeV}$ ) were measured to calculate the amount of $\mathrm{Cu}$ and $\mathrm{Cr}$, respectively.

Other radionuclides used in investigations of sorbents' characteristics as labels of ions and organic substances are given in Table 1.

Table 1. Radionuclides used as labels.

\begin{tabular}{llll}
\hline Elements & Radionuclides & $\mathbf{T}_{\mathbf{1} 2 \mathbf{2}}$ & $\mathbf{E}_{\boldsymbol{\gamma}}, \mathbf{M e V}$ \\
\hline $\mathrm{M}-{ }^{32} \mathrm{P}$ & ${ }^{32} \mathrm{P}$ & $14.3 \mathrm{~d}$ & $\mathrm{E}_{\beta}=1.7$ \\
$\mathrm{Cr}(\mathrm{VI})$ & ${ }^{51} \mathrm{Cr}$ & $27.73 \mathrm{~d}$ & 0.320 \\
$\mathrm{Co}(\mathrm{II})$ & ${ }^{60} \mathrm{Co}$ & $5.27 \mathrm{y}$ & $1.17,1.33$ \\
$\mathrm{Ni}(\mathrm{II})$ & ${ }^{65} \mathrm{Ni}$ & $2.5 \mathrm{~h}$ & 1.480 \\
$\mathrm{Cu}(\mathrm{II})$ & ${ }^{64} \mathrm{Cu}$ & $12.7 \mathrm{~h}$ & 0.511 \\
$\mathrm{Zn}(\mathrm{II})$ & ${ }^{65} \mathrm{Zn}$ & $244.1 \mathrm{~d}$ & 1.115 \\
$\mathrm{Br}(\mathrm{I})$ & ${ }^{82} \mathrm{Br}$ & $35.3 \mathrm{~h}$ & 0.776 \\
$\mathrm{Sr}(\mathrm{II})$ & ${ }^{89} \mathrm{Sr}$ & $50.5 \mathrm{~d}$ & 0.909 \\
$\mathrm{M}-{ }^{99} \mathrm{Mo}+{ }^{99 \mathrm{~m}} \mathrm{Tc}$ & ${ }^{99} \mathrm{Mo}+{ }^{99 \mathrm{~m}} \mathrm{Tc}$ & $66 \mathrm{~h}(6.0 \mathrm{~h})$ & 0.140 \\
$\mathrm{Cd}(\mathrm{II})$ & ${ }^{115} \mathrm{Cd}$ & $53.5 \mathrm{~h}$ & 0.336 \\
$\mathrm{Sb}(\mathrm{II})$ & ${ }^{124} \mathrm{Sb}$ & $60.2 \mathrm{~d}$ & 1.691 \\
$\mathrm{M}-{ }^{131} \mathrm{I}$ & ${ }^{131} \mathrm{I}$ & $8.04 \mathrm{~d}$ & 0.364 \\
$\mathrm{Cs}(\mathrm{I})$ & ${ }^{134} \mathrm{Cs}$ & $2.07 \mathrm{y}$ & 0.605 \\
\hline
\end{tabular}

The exchange capacity $\mathrm{Q}$, meq/g, was calculated by Equation (1):

$$
\mathrm{Q}=\left(\mathrm{A}_{0}-\mathrm{A}_{\mathrm{e}}\right) /\left(\mathrm{A}_{0}-\mathrm{A}_{\mathrm{B}}\right) \mathrm{B} / \mathrm{W}
$$

where $\mathrm{B}$ is the carrier amount, meq; $\mathrm{W}$ is the exchanger weight, $\mathrm{g} ; \mathrm{A}_{0}$ is a count rate of the original solution; $\mathrm{A}_{\mathrm{e}}$ is a count rate of the solution at equilibrium; $A_{B}$ is a background count.

The distribution coefficient $\mathrm{K}_{\mathrm{d}}$ and the percent adsorption $\mathrm{P}$ were calculated by Equations (2), (3):

$$
\begin{gathered}
K_{d}=\left(\left(A_{0}-A_{B}\right) /\left(A_{e}-A_{B}\right)-1\right) V / W \\
P=100\left(1-\left(A_{e}-A_{B}\right) /\left(A_{0}-A_{B}\right)\right)
\end{gathered}
$$

where $\mathrm{V}$ is a total volume of the solution, $\mathrm{ml}$.

The sorption processes of ions from water in dynamic conditions were studied by using columns with a diameter of $12 \mathrm{~mm}$; the weight of sorbents was $1 \mathrm{~g}$.

\section{Results and Discussion}

The kinetics of saponification of the fibers and the alteration of linkage quality between the polyester fiber and the polyacrylonitrile layer after chemical treatment of filters were studied in the range of $\mathrm{NaOH}$ solution concentration from 1 to $10 \%$. For example, the results for concentration of $5 \%$ are given in Figures 1 and 2.

An increase in solution treatment temperature and treatment duration causes filter capacity increase, but linkage between the polyester fiber and the polyacrylonitrile layer is attenuated and the layer begins scattering. Thus, the treatment with a $5 \%$ solution of $\mathrm{NaOH}$ at $45-50^{\circ} \mathrm{C}$ for 1 hour was selected as the optimal condition for cation exchange sorbents production. The exchange capacity $\left(\mathrm{Cu}^{2+}\right)$ of the sorbents is $0.25 \mathrm{meq} / \mathrm{g}$.

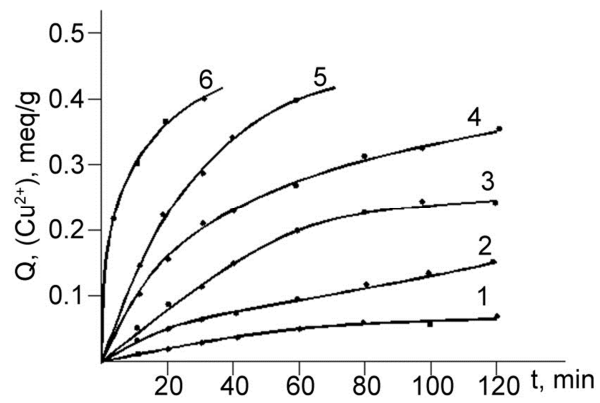

Figure 1. Kinetics of saponification of the fibers in a $5 \% \mathrm{NaOH}$ solution at $25^{\circ} \mathrm{C}(1), 30^{\circ} \mathrm{C}(2), 40^{\circ} \mathrm{C}(3), 50^{\circ} \mathrm{C}(4), 70^{\circ} \mathrm{C}$ (5) and $90^{\circ} \mathrm{C}(6)$.

Anion exchange sorbents are made by treatment of cation exchange filters in an $\mathrm{H}$-form with a water solution of polyethylenimine. Amine groups attach to carboxy groups by electrostatic forces. The kinetics of anion exchange groups' formation at concentrations of polyethylenimine from 0.5 to $5 \%$ and temperature from $20^{\circ} \mathrm{C}$ to $70^{\circ} \mathrm{C}$ were studied. Figure 3 demonstrates a kinetics curve at $40^{\circ} \mathrm{C}$ and a $1 \%$ concentration of polyethylenimine. Figure 4 shows dependence of exchange capacities on the concentration of polyethylenimine at $40^{\circ} \mathrm{C}$ and the treatment time of 8 hours.

The treatment of the cation exchange sorbents with a $1 \%$ solution of polyethylenimine at $40^{\circ} \mathrm{C}$ for $8-10$ hours was 
selected as the optimal condition for the anion exchange sorbents' production. The sorbents' capacity $\left(\mathrm{Cr}^{6+}\right)$ is 0.45 $\mathrm{meq} / \mathrm{g}$.

Removing heavy metal ions ( $\mathrm{Zn}, \mathrm{Ni}, \mathrm{Cu}, \mathrm{Sb}, \mathrm{Co}, \mathrm{Cd}, \mathrm{Cr}$, etc.) and organic molecules labeled by radionuclides $\left(\mathrm{M}-{ }^{32} \mathrm{P}\right.$, $\mathrm{M}-{ }^{131} \mathrm{I}, \mathrm{M}-{ }^{99} \mathrm{Mo}+{ }^{99 \mathrm{~m}} \mathrm{Tc}$, etc.) from water was studied. Dependence of the distribution coefficient $\mathrm{K}_{\mathrm{d}}$ for different ions and organic substances on the solutions' $\mathrm{pH}$ is presented in Table 2.

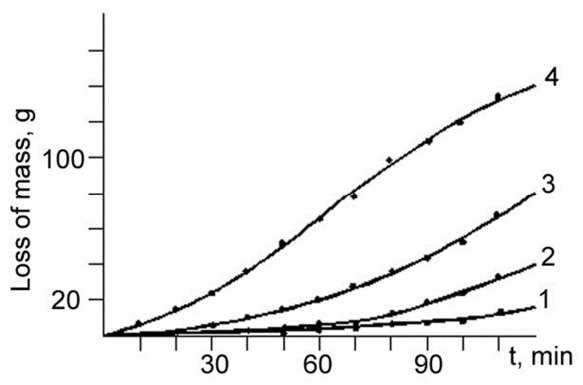

Figure 2. Change in linkage quality between polyester fibers and the polyacrylonitrile layer after chemical treatment during t minutes at $30^{\circ} \mathrm{C}(1)$, $50^{\circ} \mathrm{C}(2), 60^{\circ} \mathrm{C}(3)$ and $70^{\circ} \mathrm{C}(4)$.

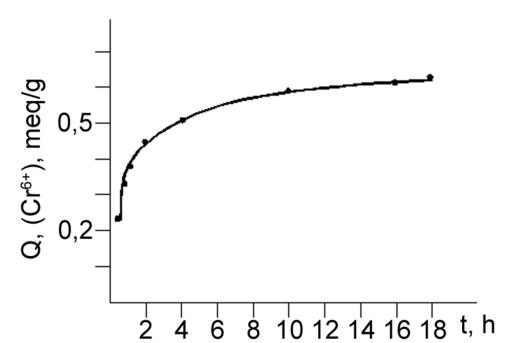

Figure 3. Kinetics of anion exchange groups' formation at $40^{\circ} \mathrm{C}$ in a $1 \%$ polyethylenimine solution.

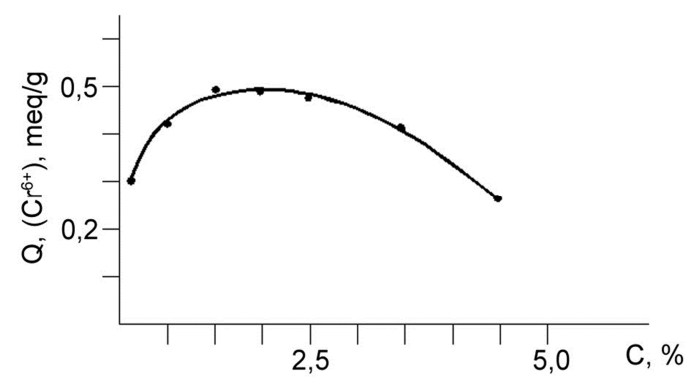

Figure 4. Dependence of exchange capacities on the concentration of polyethylenimine at $40^{\circ} \mathrm{C}$.

Table 2. The distribution coefficient $K_{d}(\mathrm{~mL} / \mathrm{g})$ for different ions and organic substances $\left(C_{0}=10 \mathrm{mg} / \mathrm{L}, \mathrm{V}=50 \mathrm{~mL}, \mathrm{W=}=0.5 \mathrm{~g}\right)$.

\begin{tabular}{|c|c|c|c|c|c|c|c|c|c|c|c|}
\hline \multirow{2}{*}{ Elements } & \multirow{2}{*}{ Exchanger } & \multicolumn{10}{|c|}{ pH of solutions } \\
\hline & & 1 & 2 & 3 & 4 & 5 & 6 & 7 & 8 & 9 & 10 \\
\hline $\operatorname{Co}(\mathrm{II})$ & Cationic & 3000 & 2600 & 2300 & 2000 & 1700 & 1000 & 126 & 138 & 150 & 160 \\
\hline $\mathrm{Ni}(\mathrm{II})$ & & 125 & 600 & 870 & 920 & 990 & 750 & 430 & 510 & 780 & 1000 \\
\hline $\mathrm{Cu}(\mathrm{II})$ & & 140 & 400 & 600 & 480 & 400 & 560 & 650 & 560 & 460 & 340 \\
\hline $\mathrm{Zn}(\mathrm{II})$ & & 230 & 2000 & 4000 & 5000 & 4000 & 1900 & 1700 & 1400 & 900 & 800 \\
\hline $\operatorname{Sr}(\mathrm{II})$ & & 11 & 25 & 45 & 100 & 300 & 1000 & 1900 & 8000 & 6000 & 900 \\
\hline $\mathrm{Sb}$ (II) & & 260 & 190 & 150 & 130 & 120 & 120 & 115 & 90 & 70 & 35 \\
\hline $\mathrm{Cs}(\mathrm{I})$ & & & 100 & 200 & 900 & 1900 & 3200 & 4000 & 4000 & 1500 & 11 \\
\hline $\mathrm{Cr}(\mathrm{VI})$ & Anionic & 200 & 150 & 100 & & & & & & & \\
\hline $\mathrm{M}-{ }^{32} \mathrm{P}$ & & & 3200 & 3000 & 2700 & 2500 & 1900 & 1100 & 300 & 150 & \\
\hline $\mathrm{M}-{ }^{131} \mathrm{I}$ & & & 3100 & 2800 & 2600 & 2300 & 2100 & 1900 & 500 & 150 & \\
\hline${ }^{99} \mathrm{Mo}+{ }^{99 \mathrm{~m}} \mathrm{Tc}$ & & & & 2900 & 2800 & 2400 & 2300 & 2000 & 500 & 140 & \\
\hline
\end{tabular}

The specific behavior of the $\mathrm{K}_{\mathrm{d}}$ of $\mathrm{Co}(\mathrm{II}), \mathrm{Ni}(\mathrm{II})$ and $\mathrm{Cu}(\mathrm{II})$ is explained by the dependence of the relation between the $\mathrm{M}^{\mathrm{n}+}$ form and hydrolyzed forms in the solution on $\mathrm{pH}$ [9]. The influence of additional foreign cations $\mathrm{Na}^{+}$and $\mathrm{K}^{+}$on the adsorption of different metals at $\mathrm{pH}=7$ is presented in Table 3 .

Table 3. The influence of additional foreign cations $\mathrm{Na}^{+}$and $\mathrm{K}^{+}$on the distribution coefficient $K_{d}(\mathrm{~mL} / \mathrm{g})$ of different ions at $\mathrm{pH}=7$.

\begin{tabular}{|c|c|c|c|c|c|}
\hline \multirow{2}{*}{ Elements } & \multicolumn{2}{|l|}{$\mathrm{Na}^{+}$} & \multicolumn{2}{|l|}{$\mathbf{K}^{+}$} & \multirow{2}{*}{$\begin{array}{l}\mathrm{Na}^{+}+\mathrm{K}^{+} \\
100+100 \mathrm{mg} / \mathrm{L}\end{array}$} \\
\hline & $10 \mathrm{mg} / \mathrm{L}$ & $100 \mathrm{mg} / \mathrm{L}$ & $10 \mathrm{mg} / \mathrm{L}$ & $100 \mathrm{mg} / \mathrm{L}$ & \\
\hline $\mathrm{Co}(\mathrm{II})$ & 130 & 140 & 130 & 140 & 140 \\
\hline $\mathrm{Ni}(\mathrm{II})$ & 510 & 300 & 520 & 420 & 500 \\
\hline $\mathrm{Cu}$ (II) & 600 & 460 & 550 & 530 & 530 \\
\hline $\mathrm{Zn}$ (II) & 1700 & 800 & 1700 & 800 & 800 \\
\hline $\mathrm{Cd}(\mathrm{II})$ & 38 & 34 & 50 & 32 & 20 \\
\hline
\end{tabular}

Adsorbed ions were eluted with a $1 \mathrm{M} \mathrm{HCl}$ solution at a flow rate of $2 \mathrm{~mL}$ per minute, and $1 \mathrm{~mL}$ fractions were collected each time for radiometric measurements. As an example, Figure 5 shows elution profiles of copper, cobalt and cadmium: activity in count per minute (CPM) per fraction is plotted against the volume of eluant. About $95 \%$ of adsorbed ions were recovered by elution with a $30 \mathrm{~mL} \mathrm{HCl}$ solution. The capacity decrease $\Delta \mathrm{Q} \%$ against a number $\mathrm{N}$ of regenerations was studied. Test results are given in Figure 6. 


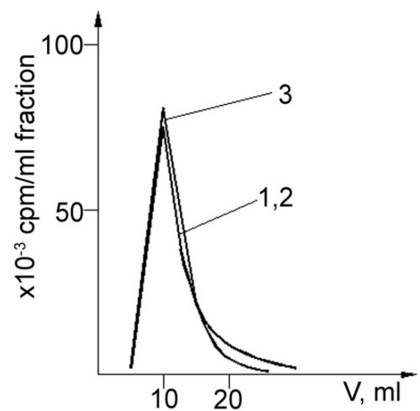

Figure 5. Elution profiles of copper, cobalt and cadmium against the volume of eluent.

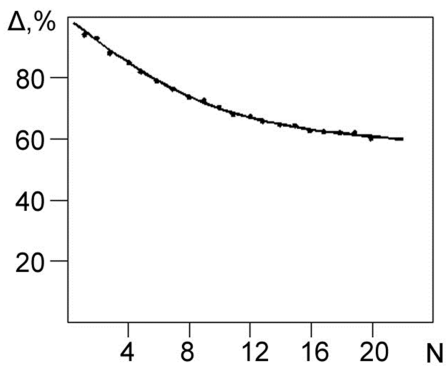

Figure 6. The capacity $\Delta Q$ decrease against a number $N$ of regenerations.

Nonwoven cloth weighing $1 \mathrm{~kg} / \mathrm{m}^{2}$ made of analogous fibers is widely used in filters with an output of 3,000 to $25,000 \mathrm{~m}^{3} / \mathrm{h}$ for removal of $\mathrm{SO}_{2}, \mathrm{SO}_{3}, \mathrm{HF}, \mathrm{HCl}, \mathrm{Cl}_{2}, \mathrm{NH}_{3}, \mathrm{H}_{2} \mathrm{~S}$, $\mathrm{NH}_{2}-\mathrm{NH}_{2}$ and other gases and liquid aerosols, the most common atmospheric pollutants [10-15].

\section{Conclusion}

The above described results of investigations show that chemically modified polyester fiber filters have satisfactory adsorption characteristics. These cation and anion exchange filters can be used for removing metal ions $(\mathrm{Zn}, \mathrm{Ni}, \mathrm{Cu}, \mathrm{Sb}, \mathrm{Co}$, $\mathrm{Cd}, \mathrm{Cr}$, etc.) and organic compounds $\left(\mathrm{M}-{ }^{32} \mathrm{P}, \mathrm{M}-{ }^{131} \mathrm{I}\right.$, $\mathrm{M}-{ }^{99} \mathrm{Mo}+{ }^{99 m} \mathrm{Tc}$, etc.) from wastewater. The cation exchange sorbents' capacity is $0.25 \mathrm{meq} / \mathrm{g}\left(\mathrm{Cu}^{2+}\right)$ while the anion exchange sorbents' capacity is $0.45 \mathrm{meq} / \mathrm{g}\left(\mathrm{Cr}^{6+}\right)$.

\section{References}

[1] Luqman I. M. (2012) Ion Exchange Technology I - Theory and Materials, Springer Science \& Business Media.

[2] Kragten J. (1978) Atlas of Metal-Ligand Equilibria in Aqueous Solution, Ellis Horwood Ltd., Chichester.
[3] Nemilova, T. V., Emets, L. V., Nemilov, V. N. et al. Fibre Chem (1996) 28: 381. doi: 10.1007/BF01061000.

[4] Zverev M. P. (1981) Fibroid chemosorbents, Chemistry, Moscow.

[5] Khaydarov R. A, Khaydarov R. R., Cho S., (2009) Natural disaster: prevention of drinking water scarcity, Threats to Global Water Security (Jones, J. et. al.: Eds.), Springer, Netherlands, pp. 381-384.

[6] Khaydarov R. A, Gapurova O., Khaydarov R. R, Cho S. Y. (2005) Fibroid Sorbents For Water Purification, in Modern Tools and Methods of Water Treatment for Improving Living Standards, NATO Science Series, 1V. Earth and Environmental Sciences - Vol. 48, pp. 101-108.

[7] Khaydarov R. A, Khaydarov R. R, (2006) Purification of drinking water from ${ }^{134,137} \mathrm{Cs},{ }^{89,90} \mathrm{Sr},{ }^{60} \mathrm{Co}$ and ${ }^{129} \mathrm{I}$, in Medical Treatment of Intoxication and Decontamination of Chemical Agent in the Area of Terrorist Attack, NATO Science Series A: Chemistry and Biology - Vol. 1, pp. 171-181.

[8] Khaydarov R. A, Khaydarov R. R (2008) Environmental Change in the Aral Sea Region: New Approaches to Water Treatment in Environmental Change and Human Security: Recognizing and Acting on Hazard Impacts, NATO Science for Peace and Security Series C: Environmental Security, Springer Netherlands, pp. 433-447.

[9] Ashirov A. (1983) Ion-exchange purification of waste water, solutions and gases, Chemistry, Leningrad, USSR.

[10] Zverev, M. P. Fibre Chem (1994) 25: 498. doi: 10.1007/BF00550794.

[11] Astapov A. V., Peregudov Y. S., Kopylova V. D. et al. (2010) The hydration characteristics of chemisorption fiber VION $\mathrm{KN}-1$ in the nickel and zinc forms. Russian Journal of Physical Chemistry A, vol. 84, pp 491-494.

[12] Khaydarov R. R., Gapurova O., Khaydarov R. A etc «The Application of Fibrous Ion-Exchange Sorbents for Water Treatment and the Purification of Gaseous Mixtures», Advances in Materials Science Research. Nova Science Publishers, Volume 30, 2017, pp. 229-239.

[13] M. Young (1989) The Technical Writer's Handbook. Mill Valley, CA: University Science.

[14] Khaydarov R. A., Khaydarov R. R., Gapurova O. U., Nasirova N. (2013) VOC Degradation in the Atmosphere by Nanophotocatalysts. In: Barnes, I (ed) Disposal of Dangerous Chemicals in Urban Areas and Mega Cities, NATO Science for Peace and Security Series C: Environmental Security.Springer (Netherlands), pp. 139-150.

[15] Khaydarov R. R., Khaydarov R. A., Mironov V., Gapurova O. Malikov Sh. (2007) Using fibrous sorbents for water treatment from radionuclides. Uzbek Journal of Physics. Tashkent, vol. 9 (2), pp. 144-150. 